\title{
Chemical Looping Combustion of Solid Fuels in a Laboratory Fluidized-bed Reactor
}

\author{
H. Leion*, T. Mattisson and A. Lyngfelt \\ Chalmers University of Technology, 41296 Göteborg - Sweden \\ e-mail: leion@chalmers.se-tm@chalmers.se - anders.lyngfelt@chalmers.se \\ * Corresponding author
}

Résumé - Combustion de charges solides avec la boucle chimique dans un lit fluidisé de laboratoire - Lorsque l'on utilise des combustibles solides dans la boucle chimique (CLC pour Chemical Looping Combustion), il est nécessaire de gazéifier le char avant de faire la combustion du gaz de synthèse au contact du transporteur d'oxygène. Ces réactions peuvent s'effectuer dans le réacteur fuel, dans lequel le combustible et le transporteur d'oxygène sont bien mélangés. Cependant, la gazéification du charbon est lente et reste l'étape limitante du processus de combustion dans ces conditions. Une alternative consiste à utiliser un matériau transporteur d'oxygène capable de relarguer l'oxygène directement dans la phase gazeuse, cet oxygène pouvant ensuite réagir directement avec le combustible. Cela permet alors d'avoir des vitesses de combustion plus rapides. Cette alternative est couramment appelée CLOU (pour Chemical Looping combustion with Oxygen Un-coupling). Dans cet article, on présente une synthèse sur les paramètres qui influencent la conversion du combustible dans les modes CLC et CLOU à partir de résultats obtenus en laboratoire. Le paramètre le plus important est la nature du combustible. Les combustibles contenant plus de matières volatiles se convertissent plus rapidement. Les différences dues à la nature du combustible sont plus marquées avec le CLC qu'avec le CLOU. La conversion du combustible augmente dans les deux cas avec la température. Dans le CLC, la concentration en vapeur ou en $\mathrm{SO}_{2}$ favorise également la conversion. Avec le $\mathrm{CLC}$, la gazéification par le $\mathrm{CO}_{2}$ est très lente comparativement à la gazéification à la vapeur. La présence d' $\mathrm{H}_{2}$ peut limiter la gazéification du combustible en CLC alors que la présence de $\mathrm{CO}$ ou de vapeur n'a pas d'effet a priori. Il faut faire attention à la désactivation du matériau transporteur d'oxygène en présence de cendres ou de $\mathrm{SO}_{2}$.

Abstract - Chemical Looping Combustion of Solid Fuels in a Laboratory Fluidized-bed Reactor When using solid fuel in a chemical looping system, the char fraction of the fuel needs to be gasified before syngas react with the oxygen carrier. This can be done inside the fuel reactor with fuel and oxygen carriers well mixed, and, since this gasification is comparably slow, this will be the time limiting step of such a system. An option is to use an oxygen carrier that is able to release gas-phase oxygen which can react with the fuel by normal combustion giving a significantly faster overall fuel conversion. This last option is generally referred to as Chemical Looping combustion with Oxygen Un-coupling (CLOU). In this work, an overview is given of parameters that affect the fuel conversion in laboratory CLC and CLOU experiments. The main factor determining the fuel conversion, in both CLC and CLOU, is the fuel itself. High-volatile fuels are generally more rapidly converted than low volatile fuels. This difference in fuel conversion rate is more pronounced in CLC than in CLOU. However, the fuel conversion is also, both for $C L C$ and $C L O U$, increased by increasing temperature. Increased steam and $\mathrm{SO}_{2}$ fraction in the surrounding gas will also enhance the fuel conversion in $C L C . \mathrm{CO}_{2}$ gasification in CLC appears to be very slow in comparison to steam gasification. $\mathrm{H}_{2}$ can inhibit fuel gasification in $\mathrm{CLC}$ whereas $\mathrm{CO}$ did not seem to have any effect. Possible deactivation of oxygen carriers due to $\mathrm{SO}_{2}$ or ash also has to be considered. 


\section{INTRODUCTION}

Chemical Looping Combustion (CLC) is a two-step cyclic process where an oxygen carrier is cycled between two reactors. The oxygen carrier is usually a metal oxide which first is oxidized with air in the air reactor, and then transferred to the second reactor, the fuel reactor, where the oxygen carrier reacts with a fuel. This fuel can be a gas, a liquid or a solid. The off-gas from the air reactor contains oxygen depleted air which can be emitted to the atmosphere. The flue gas from the fuel reactor contains mainly water and carbon dioxide. The water is separated by condensation, impurities, such as $\mathrm{SO}_{2}$, are removed by conventional methods. The $\mathrm{CO}_{2}$ can then be transported to a suitable storage facility such as a saltine aquifer [1]. By this arrangement the nitrogen from the combustion air is never mixed with the fuel or the flue gases; thus, costly and energy-intensive gas separation steps can be avoided. This gives CLC the potential of becoming an important technology for $\mathrm{CO}_{2}$ neutral energy production.

The amount of heat which is produced in a CLC system is equal to the amount of heat released when burning the same fuel with air. Overviews of literature concerning CLC are given by Lyngfelt et al. [2], Hossain and de Lasa [3] or Fang et al. [4].

When feeding solid fuel to the fuel reactor volatiles are released. These volatiles will react with the oxygen carrier, provided that the fuel is fed in a way that allows good contact between volatiles and oxygen carrier. Volatiles mainly contain $\mathrm{H}_{2}, \mathrm{CO}, \mathrm{CH}_{4}$ and some higher hydrocarbons. The reactions of the volatiles are therefore very similar to CLC with gaseous fuel [5]. However, the char of the solid fuel will not react directly with the oxygen carrier at any appreciable rate [6]. The char therefore needs to be gasified before the gasification products of the char can react with the oxygen carriers according to reaction (1) and (2). In these reactions the char is simplified to elementary carbon $\mathrm{C}$ :

$$
\begin{gathered}
\mathrm{C}+\mathrm{H}_{2} \mathrm{O} \Rightarrow \mathrm{CO}+\mathrm{H}_{2} \\
\mathrm{C}+\mathrm{CO}_{2} \Rightarrow 2 \mathrm{CO}
\end{gathered}
$$

During gasification the water-gas shift reaction can take place in the gas phase according to reaction (3):

$$
\mathrm{CO}+\mathrm{H}_{2} \mathrm{O} \Rightarrow \mathrm{CO}_{2}+\mathrm{H}_{2}
$$

The gasification products can react with, and thereby reduce, the oxygen carrier according to reaction (4) or (5):

$$
\begin{aligned}
& \mathrm{Me}_{X} \mathrm{O}_{Y}+\mathrm{H}_{2} \Rightarrow \mathrm{Me}_{X} \mathrm{O}_{Y-1}+\mathrm{H}_{2} \mathrm{O} \\
& \mathrm{Me}_{X} \mathrm{O}_{Y}+\mathrm{CO} \Rightarrow \mathrm{Me}_{X} \mathrm{O}_{Y-1}+\mathrm{H}_{2} \mathrm{O}
\end{aligned}
$$

The oxygen carrier is then circulated to the air reactor where it is oxidized according to reaction (6):

$$
\mathrm{Me}_{X} \mathrm{O}_{Y-1}+\mathrm{O}_{2} \Rightarrow 2 \mathrm{Me}_{X} \mathrm{O}_{Y}
$$

This process is repeated as the oxygen carrier again is re-circulated to the fuel reactor.

Most of the CLC research has been focused on gaseous fuels, such as $\mathrm{CH}_{4}$ or syngas. Experimental work on the application of CLC to solid fuels includes work at Chalmers, summarized in this paper, as well as work by Lyon and Cole [7], Shen et al. [8-10], Rubel et al. [11] and Dennis et al. [12, 13].

It is possible to avoid the generally very slow gasification step in reaction (1) and (2) by using an oxygen carrier that is able to release gas-phase oxygen in the fuel reactor according to reaction (7):

$$
2 \mathrm{Me}_{X} \mathrm{O}_{Y} \Rightarrow 2 \mathrm{Me}_{X} \mathrm{O}_{Y-1}+\mathrm{O}_{2}
$$

The released oxygen can then react with the fuel in the fuel reactor by normal combustion, see reaction (8):

$$
\mathrm{C}+\mathrm{O}_{2} \Rightarrow \mathrm{CO}_{2}
$$

This last option is generally referred to as Chemical Looping combustion with Oxygen Un-coupling (CLOU) [14]. CLOU utilize the thermodynamic properties of some oxide systems to release $\mathrm{O}_{2}$ at low oxygen partial pressures, such as in the fuel reactor, and take up $\mathrm{O}_{2}$ at high oxygen partial pressures, such as in the air reactor. Examples on three possible CLOU systems and their dependency on temperature are presented in Figure 1.

As the oxygen released is efficiently removed by the fuel in the fuel reactor, this will maintain the oxygen partial pressure below the equilibrium partial pressure; hence forcing the oxygen carrier to release even more oxygen. The amount of heat which is produced in a CLOU system is,

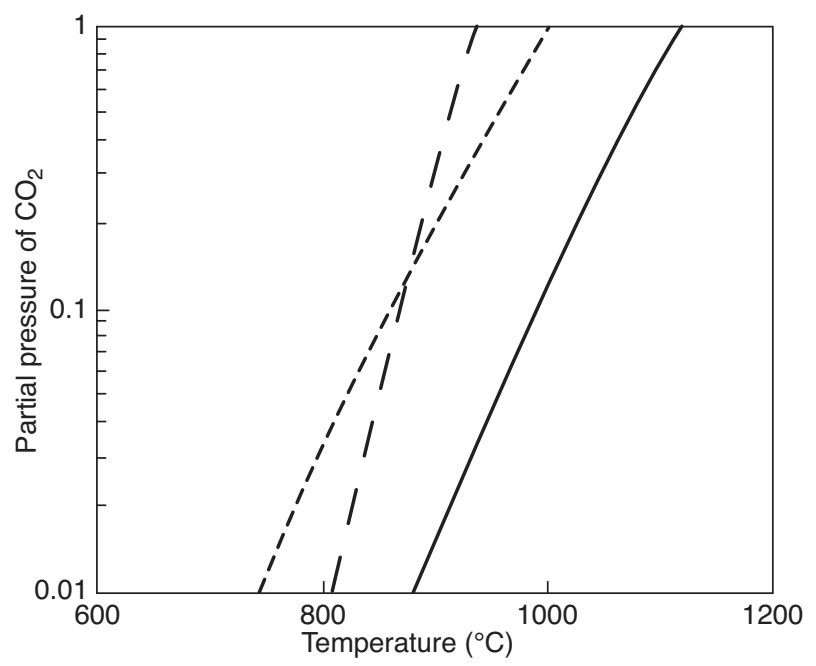

Figure 1

Partial pressure of gas phase $\mathrm{O}_{2}$ of the metal oxide systems $\mathrm{CuO} / \mathrm{Cu}_{2} \mathrm{O}(-), \mathrm{Mn}_{2} \mathrm{O}_{3} / \mathrm{Mn}_{3} \mathrm{O}_{4}(---)$ and $\mathrm{Co}_{3} \mathrm{O}_{4} / \mathrm{CoO}$ $(---)$ as a function of temperature. Calculations were performed using HSC for Chemistry 6.1. [16]. 
just as regular CLC, equal to the amount of heat released when burning the same fuel with air. Due to the avoidance of gasification, CLOU generally gives much higher fuel conversion rates and much more complete fuel conversion than conventional CLC [15].

In this work an overview is given of the laboratory research at Chalmers concerning CLC and CLOU with a focus on parameters that affect solid fuel conversion.

\section{EXPERIMENTAL}

Experiments related in this work were conducted with a fluidized-bed reactor of inert quartz placed in an oven. The reactor had a total length of $870 \mathrm{~mm}$ with a porous quartz plate placed $370 \mathrm{~mm}$ from the bottom of the reactor. In order to achieve good solid mixing in the bed, the reactor was conically shaped just above the distributor plate. A sample of oxygen carriers $(15-40 \mathrm{~g})$ was placed on the porous plate and was then initially heated to the reaction temperature $\left(800-1100^{\circ} \mathrm{C}\right)$ in an oxidizing atmosphere. The bed was then alternately exposed to a flow of oxygen in nitrogen and fuel (0.1-0.5 $\mathrm{g}$ of solid fuel/cycle), thus simulating the cyclic conditions of a CLC or CLOU-system with consecutive alternating oxidizing and reducing conditions. In fuel periods, steam, $\mathrm{SO}_{2}$ or $\mathrm{CO}_{2}$ in $\mathrm{N}_{2}$ was used as fluidizing gas during CLC experiments and $\mathrm{N}_{2}$ or steam in $\mathrm{N}_{2}$ was used during CLOU experiments. Nitrogen gas was also introduced during an inert period after each oxidizing and reducing period in order to flush the reactor from the gases in the previous cycle.

In order to avoid steam condensation in the fuel feeding device, and to facilitate the injection of the solid fuel, an additional flow of nitrogen was added at the top of the reactor together with the solid fuel. However, this sweep gas did not enter the hot reaction zone of the reactor and did therefore not influence the experiments. Since the solid fuel was injected in the top of the reactor, before it fell down in the bed of oxygen carrier, most or all of the volatiles in the fuel were released before the char fraction of the fuel got mixed in with the oxygen carrier. Therefore, due to the injection configuration, most of the volatiles did not have sufficient time to react with the oxygen carrier and therefore left the reactor unconverted. An overview of the experimental setup is presented in Figure 2.

Experiments were repeated in this manner for 3-5 cycles for each test case. The test cases involved different temperatures, different fuels or different composition of the fluidizing gas.

The gas exiting from the reactor was directed to an electric cooler, where the water was removed, and then to a gas analyzer (Rosemount NGA-2000) where the concentrations of $\mathrm{CO}_{2}, \mathrm{CO}, \mathrm{CH}_{4}, \mathrm{O}_{2}$ and, in some cases, $\mathrm{SO}_{2}$ and $\mathrm{H}_{2}$ were measured in addition to the gas flow. The temperature in, and

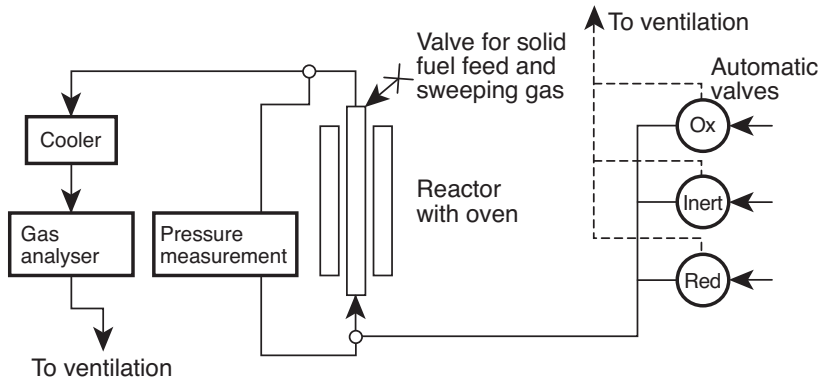

Figure 2

Overview of the experimental setup.

slightly below, the bed was measured by two thermocouples with an accuracy of $\pm 5^{\circ} \mathrm{C}[17,18]$. High frequency measurements of the pressure drop over the bed were also conducted in order to determine if the bed was fluidized or not.

Most CLC experiments were conducted using the $\mathrm{Fe} / \mathrm{Ti}$ mineral ilmenite as oxygen carrier $[15,18-20]$ and most CLOU experiments were done with a freeze granulated $\mathrm{Cu}-$ base particle $\left(40 \% \mathrm{CuO}\right.$ on $\left.\mathrm{ZrO}_{2}\right)$ as oxygen carrier $[15,21]$. However, also other oxygen carriers were used for some of the experiments [17, 18, 22-24]. A wide range of solid fuels with different content of sulphur, ash volatiles and other species were tested [25-27].

\section{RESULTS}

\subsection{Temperature Dependence}

Fuel conversion in CLC is enhanced by high temperatures. In Figure $3 \mathrm{a}$ the rate to convert $95 \%$ of the fuel is presented. It should be clarified that this is the average rate for $95 \%$ conversion, hence the rate or level of fuel conversion at a given time during the experiment can be higher or lower.

The oxidation of the oxygen carriers in the air reactor in the case of regular CLC is generally fast at all temperatures of interest. This means that high temperatures can be targeted since this enhances fuel conversion in a CLC fuel reactor $[9,17,28]$. Successful CLC experiments were done at temperatures as high as $1100^{\circ} \mathrm{C}$ (see Fig. 3a). As long as the temperature stays well below the melting temperature of the oxygen carrier [29] even higher temperatures could be considered in CLC if the equipment is adjusted accordingly.

Higher temperatures also increase the fuel conversion in CLOU ( see Fig 3b). However, for CLOU, oxidation of particles has to take place at a temperature where the oxygen carriers have a suitable thermodynamic partial pressure of $\mathrm{O}_{2}$. In the case of $\mathrm{Cu}$-based CLOU particles temperatures over 

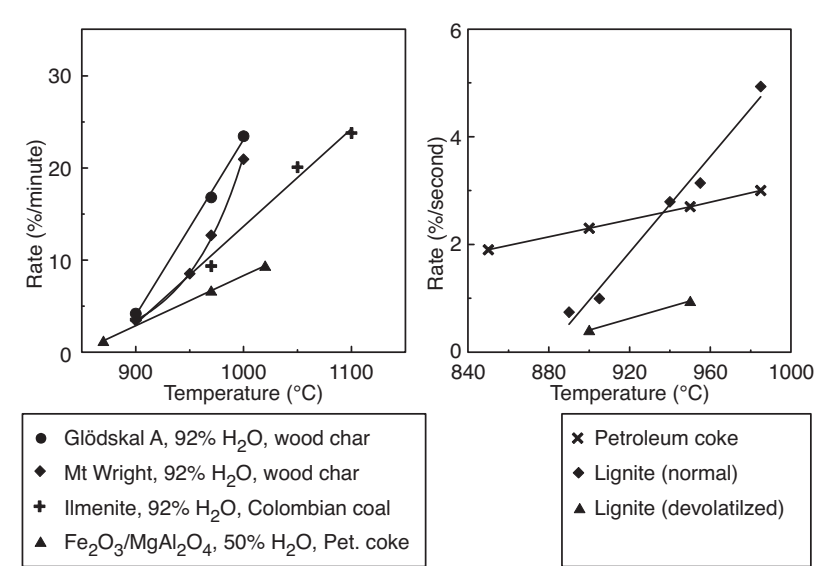

a)

Figure 3

Rate of fuel conversions as a function of temperature for four oxygen carriers in CLC a) and for $\mathrm{CuO}$ on $\mathrm{ZrO}_{2}$ in CLOU b).

$950^{\circ} \mathrm{C}$ would require an outgoing $\mathrm{O}_{2}$ concentration in the air reactor of at least $4.5 \%$ in order to re-oxidize the oxygen carrier. Figure 4 presents the thermodynamic partial pressure of oxygen for a number of temperatures together with the oxygen partial pressure obtained experimentally (see the lines represented in Fig. 4) when feeding inert gas into the reactor. As seen in Figure 4 the particles release oxygen very close to the thermodynamic partial pressures [14].

\subsection{Solid Fuel Conversion in CLC and CLOU}

The fuel conversion rates with CLOU are significantly faster than in CLC due to the fundamental difference in reaction paths (see reaction 1 to 8 ). The second most important factor determining the fuel conversion, in both CLC and CLOU, is the fuel itself, Table 1 [15]. High-volatile fuels are generally more rapidly converted than low volatile fuels [31].

TABLE 1

Time for $95 \%$ fuel conversion at $970^{\circ} \mathrm{C}$ in CLC with ilmenite and at $950^{\circ} \mathrm{C}$ in $\mathrm{CLOU}$ with $\mathrm{CuO}$ on $\mathrm{ZrO}_{2}$

\begin{tabular}{c|c|c|c|c|c}
\hline $\begin{array}{c}\text { Time for 95\% } \\
\text { conversion (s) }\end{array}$ & $\begin{array}{c}\text { Petroleum } \\
\text { coke }\end{array}$ & $\begin{array}{c}\text { Indonesian } \\
\text { coal }\end{array}$ & $\begin{array}{c}\text { Colombian } \\
\text { coal }\end{array}$ & $\begin{array}{c}\text { German } \\
\text { lignite }\end{array}$ & $\begin{array}{c}\text { Wood } \\
\text { char }\end{array}$ \\
\hline CLOU & 41 & 30 & 51 & 25 & 28 \\
\hline CLC & 648 & 282 & 606 & 84 & 378 \\
\hline
\end{tabular}

The difference in fuel conversion rate is more pronounced in CLC than in CLOU. For example in CLC the German lignite is almost 8 times faster converted than petroleum coke. But the difference between the conversion times of the same fuels using CLOU is not even a factor two.

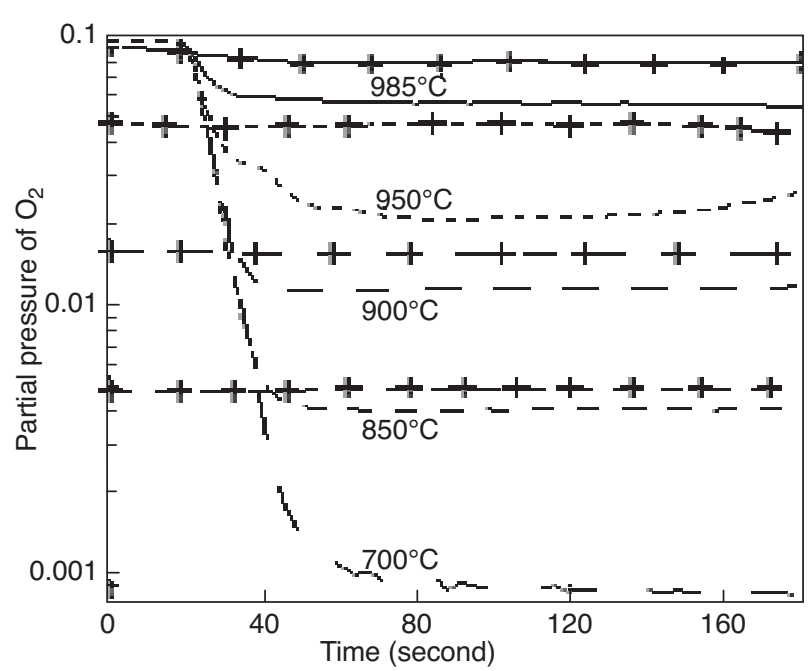

Figure 4

The partial pressure of gas phase $\mathrm{O}_{2}$ as a function of time and temperature for the $\mathrm{CuO} / \mathrm{ZrO}_{2}$ oxygen carrier. The equilibrium partial pressure $(+)$ is calculated from temperature measurements in the bed [30].

Whereas the reaction between a CLC oxygen carrier and the gasification products is fast (reaction 4 and 5) the gasification of the fuel char is slow (reaction 1 and 2) which limits the overall fuel conversion in CLC. In CLOU the release of $\mathrm{O}_{2}$ and the reaction between fuel and $\mathrm{O}_{2}$ can both limit the reaction rate depending on the fuel and oxygen carrier used [15]. In the case of German lignite and a $\mathrm{Cu}$-based oxygen carrier all oxygen released by the $\mathrm{Cu}$ oxygen carrier is rapidly consumed by the fuel, leaving only $\mathrm{CO}_{2}$ and some unconverted $\mathrm{CO}$ in the flue gases. In the case of petroleum coke, with the same oxygen carrier, the reaction between fuel and $\mathrm{O}_{2}$ is slightly slower than the release of oxygen from the same $\mathrm{Cu}$ based oxygen carrier. This leaves only $\mathrm{CO}_{2}$ and a small surplus of $\mathrm{O}_{2}$ in the flue gases. However, both the release of oxygen from the oxygen carrier and the reaction between fuel and $\mathrm{O}_{2}$ are faster or much faster than the limiting fuel gasification reaction in CLC.

If the release of oxygen is the limiting step for a specific combination of CLOU oxygen carrier and fuel, it is possible to increase the fuel conversion by simply increasing the amount of oxygen carrier for the same amount of fuel [32]. This will increase the amount of oxygen released and thereby the fuel conversion. A similar increase of the amount of oxygen carrier material in CLC will not have any significant effect on the fuel conversion. Since CLC is limited by the gasification rate of the fuel conversion is governed by the gases and temperature surrounding the fuel and not by the amount of oxygen carrier as long as there is a sufficient amount of oxygen carrier $[17,23]$. The oxygen carrier can of 
course have a secondary effect if it influences the surrounding gas, for example by decreased hydrogen inhibition as described below.

\subsection{Effect of Fuel Particle Size}

Figure 5 presents the conversion rate in CLC as a function of the outer surface area of the fuel particles. The surface area was determined with digital imaging and gives the outer surface area of a fuel particle. Note that outer surface area is inversely proportional to the particle size. Consequently, Figure 5 shows that the size of the fuel does not have any significant effect on the fuel conversion rate when varied between 90 and $355 \mu \mathrm{m}$ [24]. This is in line with gasification literature where coal gasification at temperatures below about $1000^{\circ} \mathrm{C}$ are controlled by the chemical reaction rather than by diffusion, and that the reaction takes place throughout the particle and not only at the surface [33].

Clearly, if the fuel particles were significantly larger, transport resistance within the fuel particles might become important and may then affect the fuel conversion rate.

\subsection{Gas Conversion in CLC and CLOU}

Since the fuel and oxygen carriers are well mixed in a CLC fuel reactor, there will always be a fraction of the gasification products which will not have sufficient contact with the oxygen carrier. Because of this gas from the fuel reactor will never be completely oxidized in CLC. This can be avoided in CLOU since the released $\mathrm{O}_{2}$ can react not only with the fuel in the

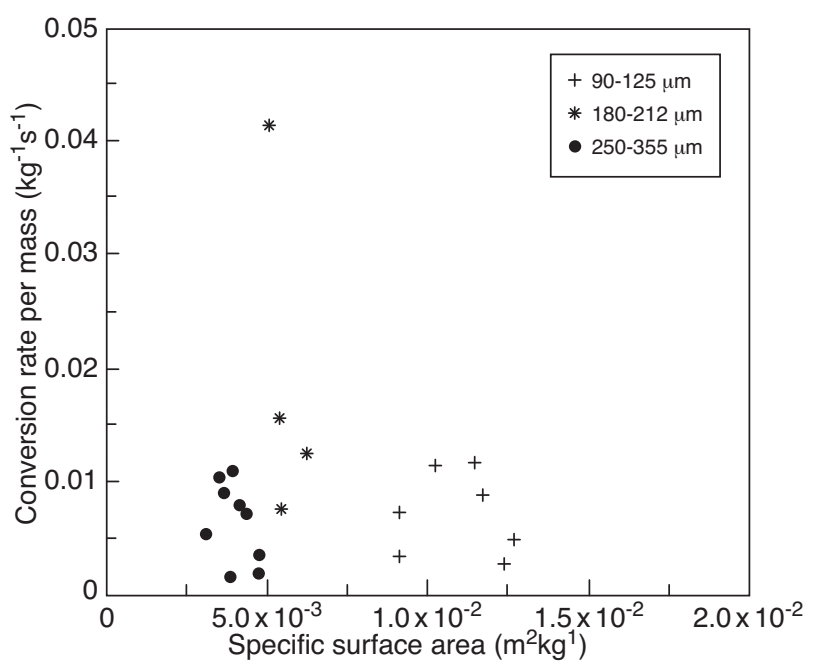

Figure 5

Mean conversion rate per mass remaining in a CLC reactor as a function of apparent surface area of the fuel particles. bed but also with the gasification products over the bed where the concentration of oxygen carrier is low [15]. From Table 2 it is obvious that CLOU gives a significantly smaller fraction of $\mathrm{CO}$ than comparable CLC experiments. A large fraction of the $\mathrm{CO}$ released in both the CLC and CLOU experiments are due to volatiles that do not have sufficient time to react with the oxygen carrier before leaving the reactor.

TABLE 2

Fraction of $\mathrm{CO}(\%)$ for experiments done at $970^{\circ} \mathrm{C}$ in CLC with ilmenite and at $950^{\circ} \mathrm{C}$ in $\mathrm{CLOU}$ with $\mathrm{CuO}$ on $\mathrm{ZrO}_{2}$

\begin{tabular}{c|c|c|c|c|c}
\hline $\begin{array}{c}\text { Fraction } \\
\text { of CO }(\%)\end{array}$ & $\begin{array}{c}\text { Petroleum } \\
\text { coke }\end{array}$ & $\begin{array}{c}\text { Indonesian } \\
\text { coal }\end{array}$ & $\begin{array}{c}\text { Colombian } \\
\text { coal }\end{array}$ & $\begin{array}{c}\text { German } \\
\text { lignite }\end{array}$ & $\begin{array}{c}\text { Wood } \\
\text { char }\end{array}$ \\
\hline CLOU & 0.1 & 3.7 & 3.3 & 4.8 & 0.6 \\
\hline CLC & $8.0(4.6)$ & 37 & $26(17)$ & 62 & $21(15)$ \\
\hline
\end{tabular}

For some of the fuels tested, the fraction of $\mathrm{CO}$ between $30 \%$ to $70 \%$ fuel conversion is given within brackets. After $30 \%$ conversion the major part of the volatiles has left the reactor and under $70 \%$ conversion there still is a significant amount of the fuel left in the bed. Unfortunately it was not possible to calculate a meaningful value for the CLOU experiments or for the CLC experiments using fuels with high volatile content. This is since the conversion time is short and therefore volatiles are detected far into the cycle due to backmixing in the system.

As discussed above, a large fraction of $\mathrm{CO}$ released comes from volatiles that have not had sufficient contact with the oxygen carrier. By modifying the reactor arrangement, in a way that increases the contact between the oxygen carrier particles and the combustible gases (i.e. volatiles and gasification products), it should be possible to lower the fraction of $\mathrm{CO}$ in both CLC and CLOU.

There are also CLOU oxygen carriers, such as $\mathrm{CaMn}_{0.875} \mathrm{Ti}_{0.125} \mathrm{O}_{3}$, which only release a small amount of $\mathrm{O}_{2}$ but also react directly with fuel gasification products. Just as in CLOU this makes complete fuel conversion possible. It also generates faster fuel conversion than CLC even if the conversion is not as fast as in CLOU with $\mathrm{Cu}$-based oxygen carriers [22]. Other materials, such as manganese with added iron, nickel and silica [34], have similar properties.

\subsection{Fuel Gasification}

In CLC the fuel, or more specific the char part of the fuel, needs to be gasified before it can react with the oxygen carriers. Ideally, this could be done by recirculated flue gases, mainly containing $\mathrm{CO}_{2}$ [13]. However, gasification with $\mathrm{CO}_{2}$ is slow and steam is likely to be a better choice [12] since it has a significantly higher gasification rate [19]. Regardless of if steam or $\mathrm{CO}_{2}$ is used it is of course more beneficial for the gasification rate with as high concentrations of these 
gasification agents as possible. However there does not seem to be any apparent synergy resulting from mixing these two gases [19]. Further, almost all oxygen carriers react faster with $\mathrm{H}_{2}$ than with $\mathrm{CO}$, making steam more suitable for gasification since it gives a higher fraction of $\mathrm{H}_{2}$ whereas gasification with $\mathrm{CO}_{2}$ only produces $\mathrm{CO}$.

It has also been shown that the presence of $\mathrm{SO}_{2}$ enhances the fuel conversion [7, 17]. An option could therefore be to recirculate $\mathrm{SO}_{2}$ containing flue gases when using a high sulphur fuel. This can also be an option when using sulphate oxygen carriers [35].

\subsection{Inhibition of Gasification}

Gasification of char is, as mentioned above, a slow reaction compared to the other reactions that take place in a CLC fuel reactor [25]. In Figure 6 the time for gasification in an inert sand bed is compared to the time to gasify the same fuel in the presences of a reactive oxygen carrier. Gasification with an oxygen carrier is roughly 2-3 times faster. The oxygen carrier reacts fast with hydrogen which drastically reducing the inhibiting effect of this gas. Hence, this makes gasification in the presence of an oxygen carrier much faster than conventional gasification.

Different mechanisms have been suggested for explaining this inhibition effect [36]. Keller et al. [18] suggested that the dissociative hydrogen adsorption is the predominant hydrogen inhibition mechanism under the CLC laboratory conditions presented in this paper. Hence, oxygen carrier with higher reactivity with $\mathrm{H}_{2}$ would give faster overall fuel reac-

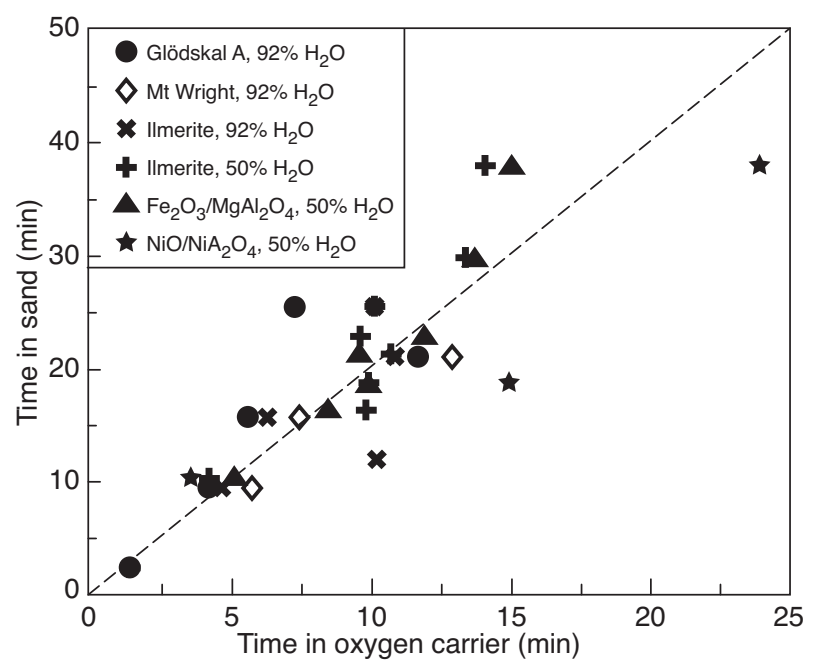

Figure 6

Time for $95 \%$ fuel conversation in a sand bed as a function of gasification in the presence of an oxygen carrier at the same temperature and the same incoming gas flow. tivity. In the same work the possible inhibiting effect of $\mathrm{CO}$ was investigated but no inhibiting effect of $\mathrm{CO}$ was observed in this work. It should be noted that $\mathrm{CO}$ inhibition has previously been discussed and detected in coal gasification. But this work, and most of the literature, indicates that hydrogen inhibition is dominating.

\subsection{Deactivation of Oxygen Carrier}

Solid fuels, like coal or lignite, contain sulphur and ash components. It is therefore possible that some of these elements can deactivate the oxygen carrier. For instance, when $\mathrm{SO}_{2}$ was added with the fuel to a bed of Ni-based oxygen carriers, fuel conversion rate was significantly reduced, likely due to the formation of sulphides [37]. Sulphur was then released in the air reactor as $\mathrm{SO}_{2}$. However, the Ni-particles regained reactivity after the additive flow of $\mathrm{SO}_{2}$ had been turned off. In other experiments, the time to convert a high sulphur petroleum coke was about $70 \%$ longer when using a Ni-based oxygen carrier than when using ilmenite as oxygen carrier [23]. In the same work, the opposite was noted for two low-sulphur bituminous coals which were converted roughly 15 and $30 \%$ faster than when using ilmenite.

It is of course also possible for CLOU oxygen carrier to be deactivated. For example when $\mathrm{CaMn}_{0.875} \mathrm{Ti}_{0.125} \mathrm{O}_{3}$ was moderately reduced with $\mathrm{CH}_{4}$ with $0.5 \%$ of $\mathrm{SO}_{2}$ mixed in with the gas during over 30 cycles, a small amount of $\mathrm{CaSO}_{4}$ was detected in the bed at the end of the experiments [32].

There are also examples of successive alterations of CLC oxygen carriers, for instance separation of $\mathrm{Fe}$ and $\mathrm{Ti}$ in ilmenite creating a $\mathrm{TiO}_{2}$ core with a shell of $\mathrm{Fe}_{2} \mathrm{O}_{3}[20,38]$. However, even this separation does not necessarily influence the fuel conversion, it can change the thermodynamic properties of the oxygen carrier system. This since the separation will result in a transformation of the ilmenite oxygen carrier from a system moving between the reduced form ilmenite and the oxidized form pseudobrookite, with a $\Delta \mathrm{H}$ of around $-445 \mathrm{~J} /\left(\mathrm{kmol}, \mathrm{O}_{2}\right)$, to an iron system supported on rutile moving between magnetite and hematite with a $\Delta \mathrm{H}$ of $-475 \mathrm{~J} /\left(\mathrm{kmol}, \mathrm{O}_{2}\right)$. Such change would give a significantly more endothermic reaction in the fuel reactor. It will also lower the amount of available oxygen in the particles.

Another example of oxygen carrier degeneration is the case of sulphate based oxygen carriers where $\mathrm{CaO}$ was formed from the $\mathrm{CaS} / \mathrm{CaSO}_{4}$ system [35].

Experiments were also performed where two different ilmenite samples were mixed with a high fraction of two different ashes [20]. For one type of ash this resulted in a somewhat lowered solid fuel conversion and lowered the oxygen carrier ability to convert $\mathrm{CH}_{4}$. But for the other type of ash the methane conversion was more or less unaffected. Also, the conversion time for a given solid fuel remained the same as before the ash addition, although the fraction of $\mathrm{CO}$ in the 
flue gases significantly increased when ash concentration in the bed increased.

\section{CONCLUSIONS}

There are two main options for chemical looping combustion of solid fuels, i.e. CLC and CLOU. The fuel conversion is considerably faster in CLOU as compared to CLC.

The fuel itself greatly affects the fuel conversion rates both in CLC and CLOU. High volatile fuels are generally more rapidly converted than low volatile fuels. The fuel conversion in CLC is governed by the rate of char gasification, and the gasification rate is strongly influenced by parameters such as temperature, steam and $\mathrm{SO}_{2}$ fraction in the surrounding gas.

Fuel conversion rate in CLOU is normally limited by release of oxygen from the oxygen carrier although oxidation of the fuel can contributes to limiting reaction in some cases.

Each CLOU material has an upper temperature limit below which the oxidation in air is practically feasible.

Gasification in CLC with $\mathrm{CO}_{2}$ is much slower than gasification with steam.

$\mathrm{H}_{2}$ has an inhibiting effect on fuel conversion in CLC. Therefore, oxygen carriers which effectively convert hydrogen give higher fuel conversion rates.

$\mathrm{SO}_{2}$ can deactivate Ni-based materials and ash can also affect oxygen carrier reactivity.

\section{ACKNOWLEDGMENTS}

This work was funded by Vattenfall AB. (Chalmers work referred to has also been carried out with support from other sources.)

\section{REFERENCES}

1 Davidson J., Thambimuthu K. (2004) Technologies for Capture of Carbon Dioxide, in 7th International Conference on Greenhouse Gas Control Technologies 2004, Vancouver, Canada.

2 Lyngfelt A., Johansson M., Mattisson T. (2008) Chemical Looping combustion - Status of development, in 9th International Conference on Circulating Fluidized Bed (CFB-9) 2008, Hamburg, Germany.

3 Hossain M.M., de Lasa H.I. (2008) Chem. Eng. Sci. 63, $4433-$ 4451.

4 Fang H., Haibin L., Zengli Z. (2009) Int. J. Chem. Eng. 2009, 16.

5 Lyngfelt A., Leckner B., Mattisson T. (2001) Chem. Eng. Sci. 56, 3101-3113.

6 Yang J.-b., Cai N.-s., Li Z.-s. (2007) Energ. Fuel. 21, 33603368 .

7 Lyon R.K., Cole J.A. (2000) Combust. Flame 121, 249-261.
8 Shen L., Wu J., Xiao J. (2009) Combust. Flame 156, 721-728.

9 Shen L., Wu J., Xiao J., Song Q., Xiao R. (2009) Energ. Fuel. 23, 2498-2505.

10 Gao Z., Shen L., Xiao J. (2008) J. Chem. Ind. Eng. 59, 12421250.

11 Rubel A., Liu K., Neatherya J., Taulbee D. (2009) Fuel 88.

12 Dennis J.S., Scott S.A., Hayhurst A.N. (2006) J. Energ. Institute 79, 187-190.

13 Scott S.A., Dennis J.S., Hayhurst A.N., Brown T. (2006) AIChE J. 52, 3325-3328.

14 Mattisson T., Lyngfelt A., Leion H. (2009) Int. J. Greenhouse Gas Control 3, 11-19.

15 Leion H., Mattisson T., Lyngfelt A. (2008) Using Chemical Looping with Oxygen Uncoupling (CLOU) for combustion six different of solid fuels, in 9th International Conference on Greenhouse Gas Control Technologies, 2008, Washington DC, USA.

16 HSC Chemistry 6.1 (2007) Chemical Reaction and Equilibrium Software, Outokumpu.

17 Leion H., Mattisson T., Lyngfelt A. (2007) Fuel 86, 1947-1958.

18 Keller M., Henrik L., Tobias M., Anders L. (2009) submitted for publication.

19 Leion H., Mattisson T., Lyngfelt A. (2009) Effects of steam and $\mathrm{CO}_{2}$ in the fluidizing gas when using bituminous coal in Chemical Looping Combustion, in 20th International Conference on Fluidized Bed Combustion, 2009, Xián, China.

20 Azis M.M., Henrik L., Jerndal E., Steenari B.-M., Tobias M., Anders L. (2009) submitted for publication.

21 Mattisson T., Leion H., Lyngfelt A. (2009) Fuel 88, 683-690.

22 Leion H., Larring Y., Bakken E., Bredesen R., Mattisson T., Lyngfelt A. (2009) Energ. Fuel. 23, 5276-5283.

23 Leion H., Mattisson T., Lyngfelt A. (2009) Chem. Eng. Res. Des. 87, 1543-1550.

24 Iggland M., Henrik L., Tobias M., Anders L. (2009) Chem. Eng. Sci., accepted.

25 Leion H., Mattisson T., Lyngfelt A. (2008) Int. J. Greenhouse Gas Control 2, 180-193.

26 Leion H., Mattisson T., Lyngfelt A. (2008) $\mathrm{CO}_{2}$ capture from direct combustion of solid fuels with Chemical Looping Combustion, in 33rd International Technical Conference on Coal Utilization \& Fuel Systems, 2008, Clearwater Florida, USA.

27 Leion H., Jerndal E., Steenari B.M., Hermansson S., Israelsson M., Jansson E., Johnsson M., Thunberg R., Vadenbo A., Mattisson T., Lyngfelt A. (2009) Fuel 88, 1945-1954.

28 Song Q., Xiao R., Deng Z., Shen L., Xiao J., Zhang M. (2008) Ind. Eng. Chem. Res. 47 Ind.

29 Jerndal E., Mattisson T., Lyngfelt A. (2006) Chem. Eng. Res. Des. 84, 795-806.

30 Leion H., Mattisson T., Lyngfelt A. (2008) Combustion of a German lignite using Chemical Looping with Oxygen Uncoupling (CLOU), in 33rd International Technical Conference on Coal Utilization \& Fuel Systems, 2008, Clearwater Florida, USA.

31 Cao Y., Casenas B., Pan W.-P. (2006) Energ. Fuel. 20, 1845 1854.

32 Leion H., Sundqvist S., Lyngfelt A., Mattisson T. (2010) submitted for publication.

33 Wen C.Y., Lee E.S. (1979) Coal conversion technology, Energy Science and Technology, Vol. 2, Addison-Wesley Educational Publishers Inc., Reading, MA, USA. 
34 Shulman A., Cleverstam E., Mattisson T., Lyngfelt A. (2009) Energ. Fuel. 23, 5269-5275.

35 Song Q., Xiao R., Deng Z., Zheng W., Shen L., Xiao J. (2008) Energ. Fuel. 22, 3661-3672.

36 Hüttinger K., Merdes W. (1992) Carbon 30, 883-894.
37 Garcia-Labiano F., de Diego L.F., Gayan P., Abad A., Abad A., Dueso C. (2009) Ind. Eng. Chem. Res. 48, 2499-2508.

38 Adánez J., Cuadrat A., Abad A., Gayán P., Diego L.d., GarcíaLabiano F. (2009) submitted for publication.

Final manuscript received in September 2010

Published online in February 2011

\section{Copyright (C) 2011 IFP Energies nouvelles}

Permission to make digital or hard copies of part or all of this work for personal or classroom use is granted without fee provided that copies are not made or distributed for profit or commercial advantage and that copies bear this notice and the full citation on the first page. Copyrights for components of this work owned by others than IFP Energies nouvelles must be honored. Abstracting with credit is permitted. To copy otherwise, to republish, to post on servers, or to redistribute to lists, requires prior specific permission and/or a fee: Request permission from Information Mission, IFP Energies nouvelles, fax. +331475270 96, or revueogst@ifpen.fr. 